\title{
THE NAPPE STRUCTURE OF THE TECTONIC WINDOW OF DOLIANA (CENTRAL PELOPONNESUS, GREECE)
}

\author{
Lekkas S. and Skourtsos E. \\ Sector of Dynamic, Tectonic and Applied Geology, Department Geology, Kapodistrian University \\ of Athens,, 157 84, Athens, eskourt@geol.uoa.gr
}

\begin{abstract}
In the tectonic window of Doliana (central Peloponnesus, Greece) a variety of geological formations occurs deriving from different sedimentation palaeoenvironments and characterized by different tectonometamorphic evolution. These rocks initially formed thrust nappes of great extension and thickness which stacked one over the other during the Lower Oligocene-Lower Miocene. The early compressing structures that were formed by the emplacement of the nappes were almost totally overprinted by the later-orogenic extension that affected the nappe-column in the Upper Miocene-Lower Pliocene. Its main tectonic characteristic was the formation of low-angle normal faults, which constitute the tectonic contacts of the nappes. These faults led to the exhumation of the formerly deeply buried metamorphic rocks that are forming the core of the tectonic window. Apart from these structures during the evolution of this deformation phase an intense thinning of the units of the upper plate took place, causing the upper units coming closer or next to the lower ones. After the Lower Pliocene a second extensional phase affected the already thinned nappe-column with the formation of high-angle normal faults.
\end{abstract}

\section{INTRODUCTION}

Recent studies on Crete (Jolivet et al., 1994, Kilias et al., 1994) and in Peloponnesus (Skourtsos, 2002) have shown that the rocks of the metamorphic units of the External Hellenides have suffered an initially plastic and later brittle deformation, which is connected to an extensional process that led to their exhumation on the earth surface. One of the main characteristics of this is the formation of low angle normal faults (detachments), which constitutes the tectonometamorphic discontinuity between the underlying metamorphic rocks of the lower units and the overlying nonmetamorphic rocks of the upper units. The latter appear faulted through various generations of normal faults, which led to their intense thinning. Such a case of intense thinning of the upper nonmetamorphic units and perhaps the best example in Peloponnesus can be seen in the region of Doliana, SE of Tripoli in central Peloponnesus, which is the subject of this study.

\section{STRUCTURAL SETTING}

The region of Doliana lies in the south-southwest of the town of Tripoli in central Peloponnesus and in the northwest part of Mount Parnon (Fig.1A). Although the study area is limited, several tectonic nappes can be observed, which represent geotectonic units deriving from different palaeogeographic enviroments, such as carbonate platforms or deep basins. The nappes - units seem to have a different tectonomatamorphic evolution and have already been placed among the known units of the External Hellenides by Lekkas (1978) (Fig. 1B).

The Plattenkalk unit can be observed on the lower part of the nappe-column (Fig. 1C). It consists of thick bedded, white-grey colored marbles that towards the top pass in flaggy marbles alternating with siliceous rocks which also pass in multicolored marbles. Compared to other outcrops of the unit on Mount Parnon and Mount Taygetos, as have been described by Thiebault (1982) and Bassias (1984), these marbles have been deposited in the Upper Cretaceous-Upper Eocene. The 
Phyllites-Quartzites unit that overlies the Plattenkalk unit is characterized by the presence of mica schists with chloritoid and glaucophane and quartzites horizons. Small occurrences of hematite and black colored thin-bedded marbles can be observed, while carbonate meta-conglomerates are found along the road to the viliage of Bourvoura.

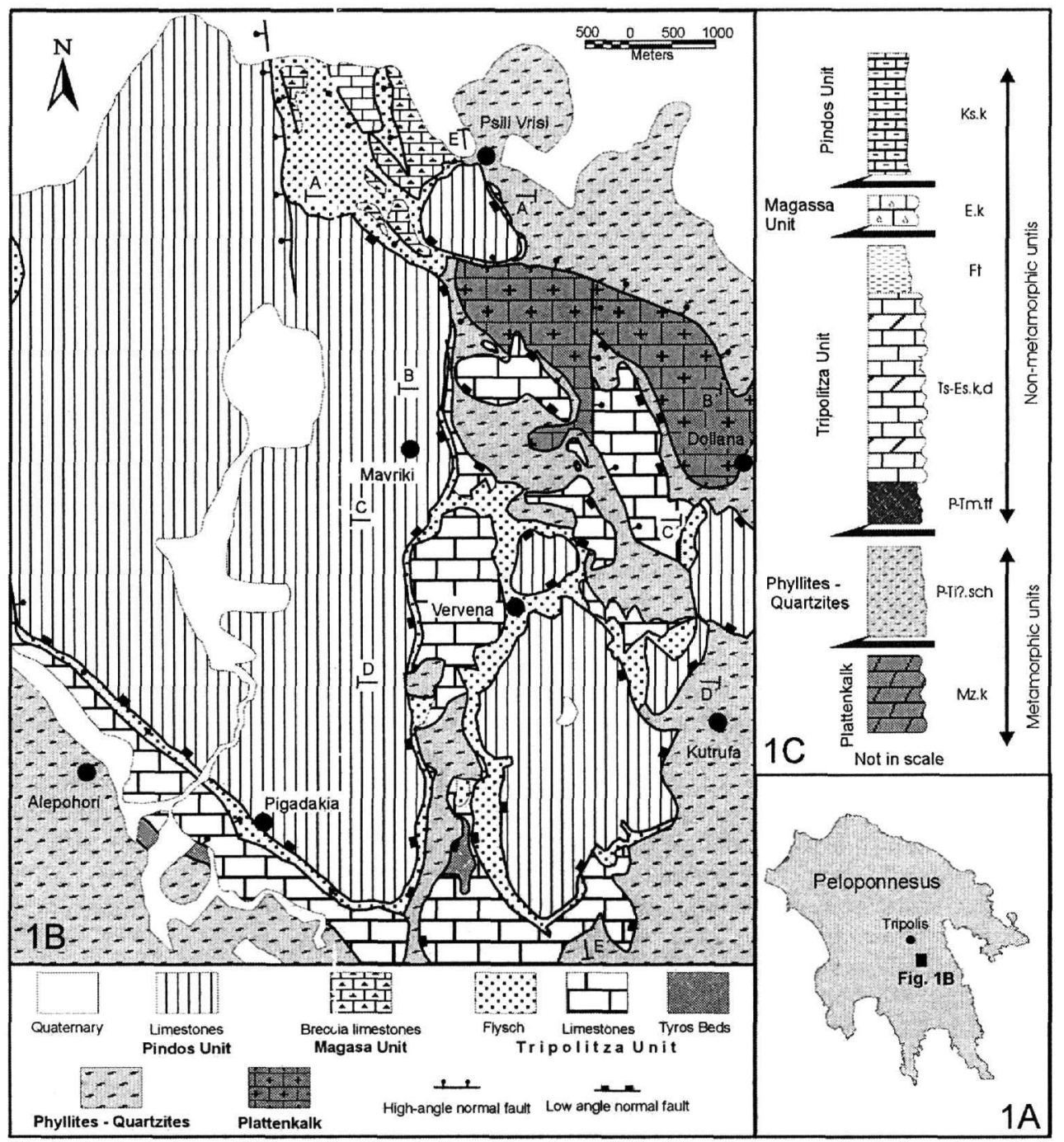

Fig. 1: Geological map (1B) and the lithostratigraphic column (1C) of the study area, situated as shown in figure $1 \mathrm{~A}$.

These two units constitute the metamorphic core of the Doliana tectonic window and have suffered metamorphism due to their subduction during Upper Oligocene-Lower Miocene. On the one hand, the Plattenkalk unit has suffered greenschist metamorphism (Thiebault, 1982, Bassias \& Tribulet, 1987, Bassias 1988, Kowalczyk \& Dittmar, 1991), while the overlying Phyllites-Quartzites unit is characterized by an initially high-pressure metamorphism which was partly overprinted by a retrograde greenschist facies during its uplift (Thiebault, 1982, Kanavos 1989, Theye \& Seidel 1991, Blümor 1998). These units tectonically underlie units, which lack metamorphism.

The lower one of the non-metamorphic units is the Tripolitza unit, which is represented in the study area with its permotrias sic base, the Tyros Beds, the carbonate platform and the flysch aged 
Upper Eocene-Lower Oligocene (Fig. 1C). The outcrops of the Tyros Beds are limited and consist of intensely foliated clastic sediments. The outcrops of the carbonate sequence is not continuous (Fig. 1B) covering stratigraphically from Upper Jurassic to Upper Eocene, while the thickness of the flysch is quite limited compared to that observed in other areas of Peloponnesus.

In the northern part of the study area, NW of Psili Vrisi and over the flysch of the Tripolitza unit there are small outcrops of carbonate breccia aged Eocene, that are placed in the Magassa unit by Lekkas \& Zambetakis-Lekkas (1980) and Bassias \& Lekkas (1989) (Fig. 1B). The clasts of these breccia limestones derive from both the Tripolitza platform and the Pindos unit. The latter composes the upper unit of the nappe-column (Fig. 1C) and shows significant surficial exposes (Fig. $1 \mathrm{~B}$ ). Contrary to what is happening in other areas of Peloponnesus, in the study area it only appears with Upper-Cretaceous thin-bedded limestones of deep basin (Lekkas 1978). In some places the upper beds of these limestones probably belong to the transitional beds to the flysch, while other times red pelites can be seen on their base which must belong to the "first flysch" of the unit, aged Cenomanian (Dercourt 1964).

\section{TECTONICS}

\subsection{Contractional Structures}

The various geotectonic units represent different palaeogeographic environments with specific arrangement from the internal Pindos deep basin to the east through the external Ionian basin to the west. The thrust imbrication and folding occurred progressively from the Lower Oligocene to Upper Miocene and from the east to the west and this process is shown in the beginning of the flysch sedimentation of each unit (Richter 1976). Thus, the nappe stacking seems to begin in Lower Oligocene when the Pindos unit overthrust the Tripolitza flysch, where the peak of this emplacement took place during Upper Oligocene-Lower Miocene. During its emplacement, Pindos nappe drifted in its base thrust slices of the Magassa unit. The overthrust of the Tripolitza unit on that of the Plattenkalk started in Upper Oligocene. In the Lower Miocene the Phyllites-Quartzites unit was subducted in 20-30 km depth, where it suffered high-pressure metamorphism and then climbed close to the earth surface thrusted on the less metamorphosed Plattenkalk rocks (Doutsos et al. 2000).

In the lower Plattenkalk geotectonic unit, this phase is displayed by a mineralogical lineation $L_{1}$ striking NE-SW, an $\mathrm{S}_{1}$ foliation, which developed parallel or almost parallel to the bedding having isoclinal folds with b-axes parallel to the lineation. In the Phyllites-Quartzites unit there is not enough evidence relating to this phase, because they were overprinted by the retrograde greenschist facies metamorphism that followed. Nevertheless, in some places where there are alternations of thin marbles layers and mica schists, overturned to isoclinal folds can be observed with relatively horizontal axes striking NE-SW.

This compression phase formed asymmetric to overturned folds, box folds, kink bands and reverse faults in the nappe of the Tripolitza unit. A lineation by intersection of axial plane and bedding was also developed in the Tyros Beds striking from NNW-SSE to N-S. The best preserved compression structures can be seen in the Tripolitza flysch beds, where reverse faults and overturned to recumbent folds can be observed, the axes of which show a main NW-SE direction with axial planes dipping ENE (Fig. 2A). In the north of the study area, Lekkas (1978) described three thrust slices of the unit near the village of Rizes, each of which consisted of limestones and flysch.

Folds striking N-S to NNE-SSW (Fig. 2B) and reverse faults striking NW-SE to N-S are mapped within the upper Pindos nappe. The asymmetry of the folds shows shearing the top to the WSW -W in agreement with the results given by Dercourt (1964) for northern Peloponnesus.

\subsection{Low-angle normal faults}

The early compression structures formed by the emplacement of the nappes have almost totally been overprinted by the subsequent extensional deformation phase. Its main tectonic feature was the formation of low-angle normal faults which are today's tectonic contacts of the nappes. During the evolution of this deformation phase an intense thinning of the units of the upper plate also took place resulting in the upper units coming closer or next to the lower ones. The study of the kinemat- 
ics of its structures shows that this phase corresponds to a non co-axial deformation with dominant sense of shear "the top to the NE-ESE".

Various extensional shear bands with sense of shear "the top to the NE-ESE" were found in the bedded limestones of the Pindos unit. Folds with ENE-WSW axes and axial planes dipping to the NW have been observed in sume places. Similar folds were found in some places in the southeast of the study area (Skourtsos, 2002).
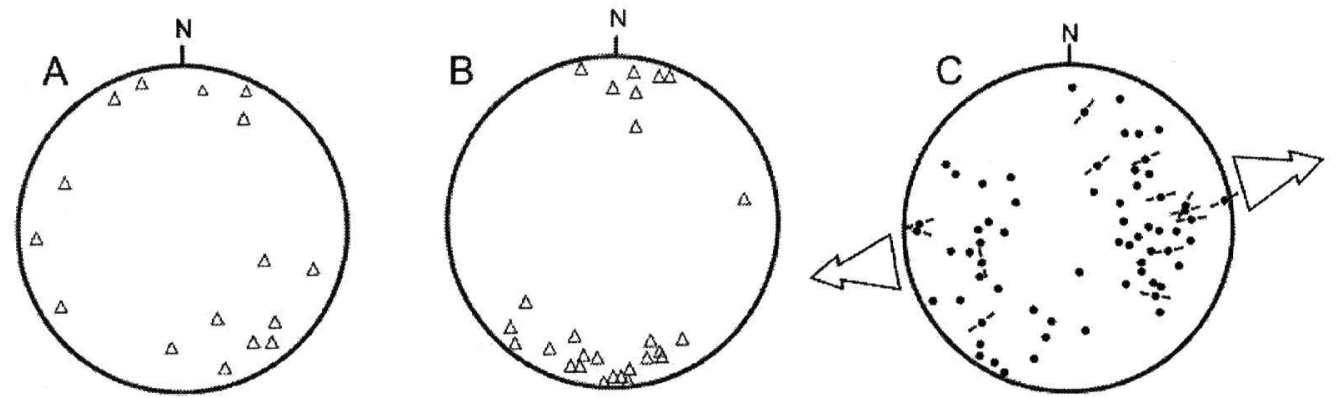

Fig. 2: Orientation of the fold axes; sampled in Tripolitza (A) and the Pindos unit (B). C) Orientation of the normal faults poles and their slickenlines sampled in the Tripoltza unit (lower hemisphere projection).

The extension of the Tripolitza unit took place with the formation of several generations of normal faults (Fig. 2C). These fe ults mainly strike NW-SE and dip to the NE and to the SW. Most of these faults show oblique slickenlines. Folds with WNW-ESE axes (Fig. 2A), S-shape foliations and extensional shear bands are formed in the flysch of the unit. The tectonic analysis of the structures above shows a dominant sense of shear "the top to the NE-ENE".

The Phyllites-Quartzites unit also seems to have suffered intense stretching. Most of the deformation observed today in the rocks of this unit relates exactly to this extension, which started in greenschist facies conditions and continued in even more surficial tectonic levels (Troté, 2000). The nature of the various tectonic structures observed in this unit, where the early plastic structures have been gradually overprinted by semiplastic and brittle structures, supports this motion. The formation of a series of tectonic structures, such as S-C structures, S-shape foliation, extensional shear bands and others show strain of the unit under intense shearing and with sense of shear "the top to the NE-ESE".

The most impressive structures of the earlier extensional phase are the formation of low-angle normal faults or detachments. These faults place the younger stratigraphic members of the Tripoltza unit, e.g. Eocene in age limestones or the flysch sediments, over the metamorphic rocks of the Phyllites-Quartzites and Flattenkalk units without the presence of the older stratigraphic members of the unit. In other places, for example in the south of Psili Vrisi and east of Vervena, the lowangle normal faults juxtapose the bedded limestones of the Pindos unit, or the breccia carbonates of the Magassa unit with the Phyllites-Quartzites unit, whereas the Tripolitza unit has been totally removed.

The detachment surfaces do not have constant geometry, but they are curved and slightly folded. In the north part of the study area the low-angle normal faults form open anticlines with NWSE axes dipping to the NW, winile in the south they are folded with NE-SW axes dipping to the SW.

These detachments are parallel for great distances or anastomose between them, something which in our opinion shows that they have acted simultaneously for a long time forming an interlaced extensional fault net wh ch led to the thinning of the upper nappes.

The upper plate of the Doliana metamorphic core is intensely faulted and thinned and this is shown by its exposed thickness that rarely reaches $150 \mathrm{~m}$. That is very interesting if compared to the thickness that the upper plate has in the east of the study area, that is, in Kynouria east of the Parnon mountain ridge, where its thickness reaches $1000 \mathrm{~m}$ and more (Skourtsos 2002). Also, the thickness of the upper nom-metamorphic nappes in the western Peloponnesus is several thousand meters (Dercourt 1964, Thieb:ault 1982). 
When observing the geolcigical map of figure 1 and the sections of figure 3 and 4 the following observations can be made for the results of this deformation phase:

-In some cases different stratigraphic horizons of the Tripolitza unit, sometimes breccia limestones of the Magassa unit and other times Upper Cretaceous limestones of the Pindos unit without the interference of sediments of the Tripolitza or Magassa unit, overlie in relatively very small distances on the metamorphic rocks of the core (Fig. 1, 3, 4).

-The contact of the metamorphic units with the rocks of the Tripolitza unit is abrupt with moderate to low dips in various directions (Fig. 3,4). This contact is characterized by $5 \mathrm{~m}$ thick cellular, reddish to yellowish brecciated dolomitic limestone.

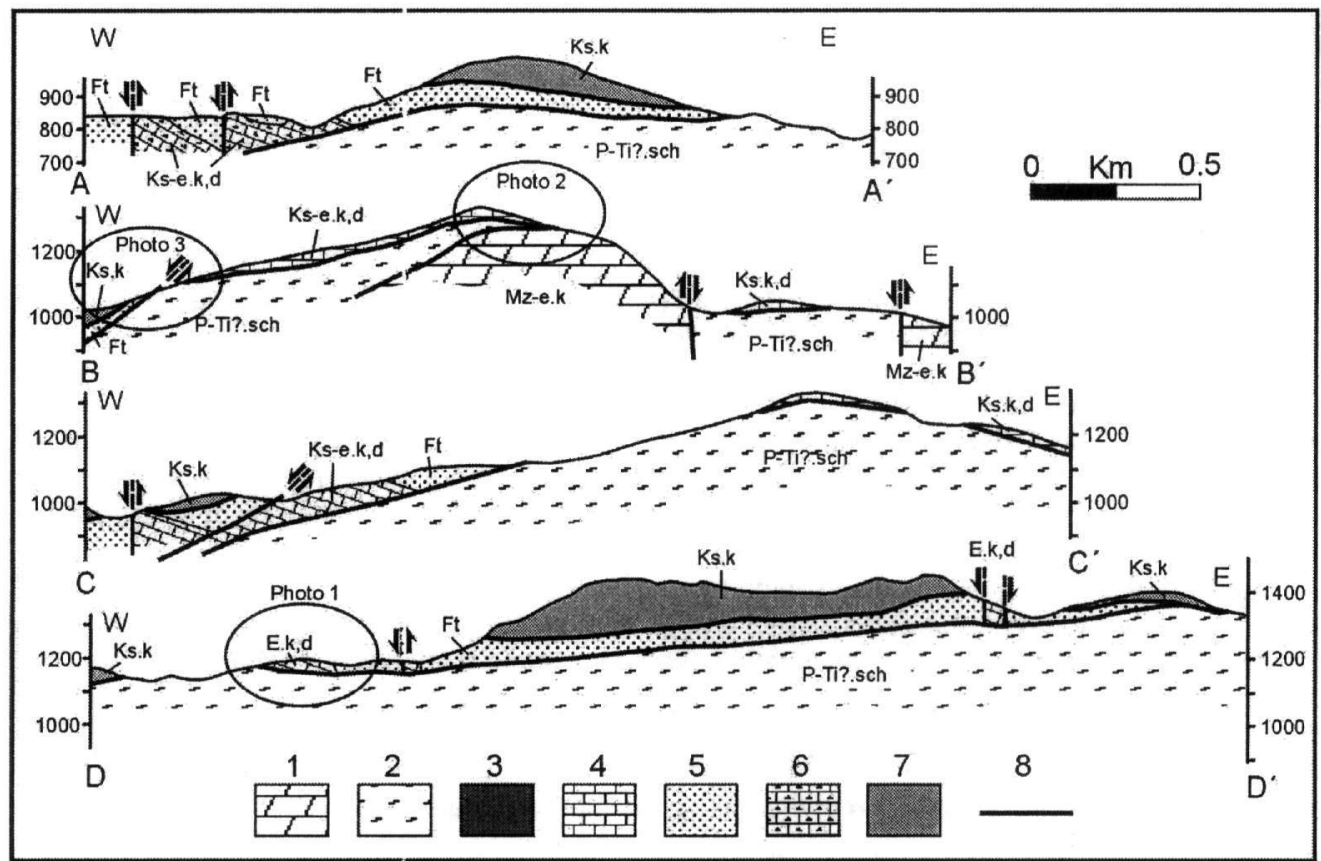

Fig. 3: Parallel E-W geological sections from the tectonic window of Doliana, where the thin nappes of the nonmetamorphic units of Tripolitza, Magassa and Pindos can be seen overlying the Phyllites-Quartzites and Plattenkalk units. The position of the sections is shown in figure 1. 1: Plattenkalk unit, 2: Phyllites-Quartzites unit, 35: Tripolitza unit, 3: Tyros Beds, 4: limestones, 5: flysch, 6: Magassa unit, 7: Pindos unit, 8: low-angle normal fault.

-Usually round the klippens of the Pindos nappe and between those and the metamorphic units, sediments of small thickness of the Tripolitza and Magassa unit are found, consisting sometimes of limestones and flysch and other times of only one of those two formations (Fig. 1,5)

-The outcrops of the sedinents of the Tripolitza and Magassa units round the carbonate klippens of the Pindos unit are issually in the form of tectonic wedges. As a result the Pindos limestones immediately overlie the Phyllites-Quartzites unit (Fig. 4).

- The contact of the Tripoltza flysch with the limestones of the Tripolitza unit is usually a normal fault. It is remarkable that in those positions where the wedge-shape outcrops of the sediments of the Tripolitza unit are observed, the fault contact between the limestones and the flysch, clearly stops on the detachment without continuing in the metamorphic basement (Fig. 5).

-In the west of Doliana village and in the north-east of Mavriki, the limestones of the Tripolitza unit overlie the marbles of the Plattenkalk unit (Fig. 5), where near the fault the bedding of the limestones is almost vertical. 


\subsection{High-angle normal faults}

The previous extensional detachment stage is followed during the Lower Pliocene by a later stage, that of the normal faults. These faults are responsible for the biggest part of the neotectonic deformation of the area. They affect all the alpine units and cut and transfer all the previous contractional and extensional structures (Fig. 3). These new fault systems consist of normal faults, striking N-S to NW-SE and E-W and having linear or curvilinear surface traces and planar or listric geometries. For the most pari, the high-angle faults are characterized by narrow breccia zones or sharp fault contacts. They are faults that, in the study area, present themselves as isolated faults, although several of those are connected to fault zones of the Tripolis plateau and the metamorphic core of Mount Parnon.

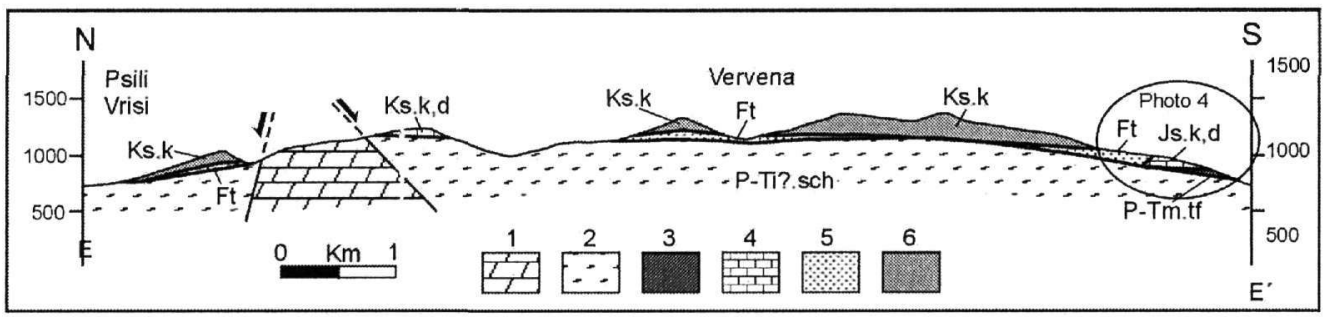

Fig. 4: Geological section E-E', where the small thickness outcrops of the Tripolitza unit can be seen sandwiched between the Pindos nappe and the Phyllites-Quartzites. 1: Plattenkalk unit, 2: Phyllites-Quartzites unit, 3-5: Tripolitza unit, 3: Tyros Beds, 4: limestones, 5: flysch, 6: Pindos unit.

\section{DISCUSSION}

This area was part of the area studied by Lekkas (1978), when it was actually mapped for the first time in detail. In his study Lekkas (1978) suggested that the contacts between the nonmetamorphic rocks and the underlying metamorphic ones is an overthrust contrary to the existing theories that considered this contact to be either unconformity (Richter 1974), or small scale slidings of the Tripolitza carbonate platform on its crystallic basement (Dercourt 1964, Tataris \& Maragoudakis 1965, De Wever 1975, Dercourt et al 1976). This study is an attempt to partly revise the origin of the nappe contacts using kinematic indicators, in which it is finally proposed that they are great scale low-angle normal aults connected to a late orogenic extensional event that affected the region after the nappe stacking and before the formation of high-angle normal faults.

So, the geological structure of the study area is the result of two successive deformation phases, an earlier compression phase that was followed by an extensional one. The compressional phase led to the formation of thrust sheets with a sense of shear "the top to the W-WSW", which consisted of rocks aged Upper Palaeozoic-Tertiary that having been detached from their basement, they formed a complex and heterogeneous nappe-column. This process was progressive, started in the Lower Oligocene and continued until the Lower Miocene. Then the nappes suffered ENE-WSW extension, that caused the int?nse thinning of the upper non-metamorphic units, the intense stretching of the Phyllites-Quartzites and the formation of low-angle normal faults.

The study area lies in the northern part of Mount Parnon, which forms an axial N-S culmination in the inner and eastern part of Peloponnesus, where high pressure rocks appear on the earth surface, underlying rocks lacking metamorphism (Doutsos 2000, Skourtsos 2002). The tectonic evolution of Mount Parnon was presented by Skourtsos (2002), who grouped the various tectonic events in three deformation phases and proposed the existence of at least five mappable detachment faults. In the same study he described a gradual raise in the strain of the non-metamorphic rocks from the east to the west and a corresponding reduction of the thickness of their nappes. Therefore, the area of Doliana is the continuity to the North of the intensely stretched and thinned upper plate of the metamorphic core of Parnon Mt. The same researcher using restored sections also showed that the stretching of the upper plate took place with the formation of a complex extensional fault net and presented the way in which the initially big thickness outcrops of the upper nappes ended forming relics of small thickness and width, which are finally extensional nappes or klippens. 


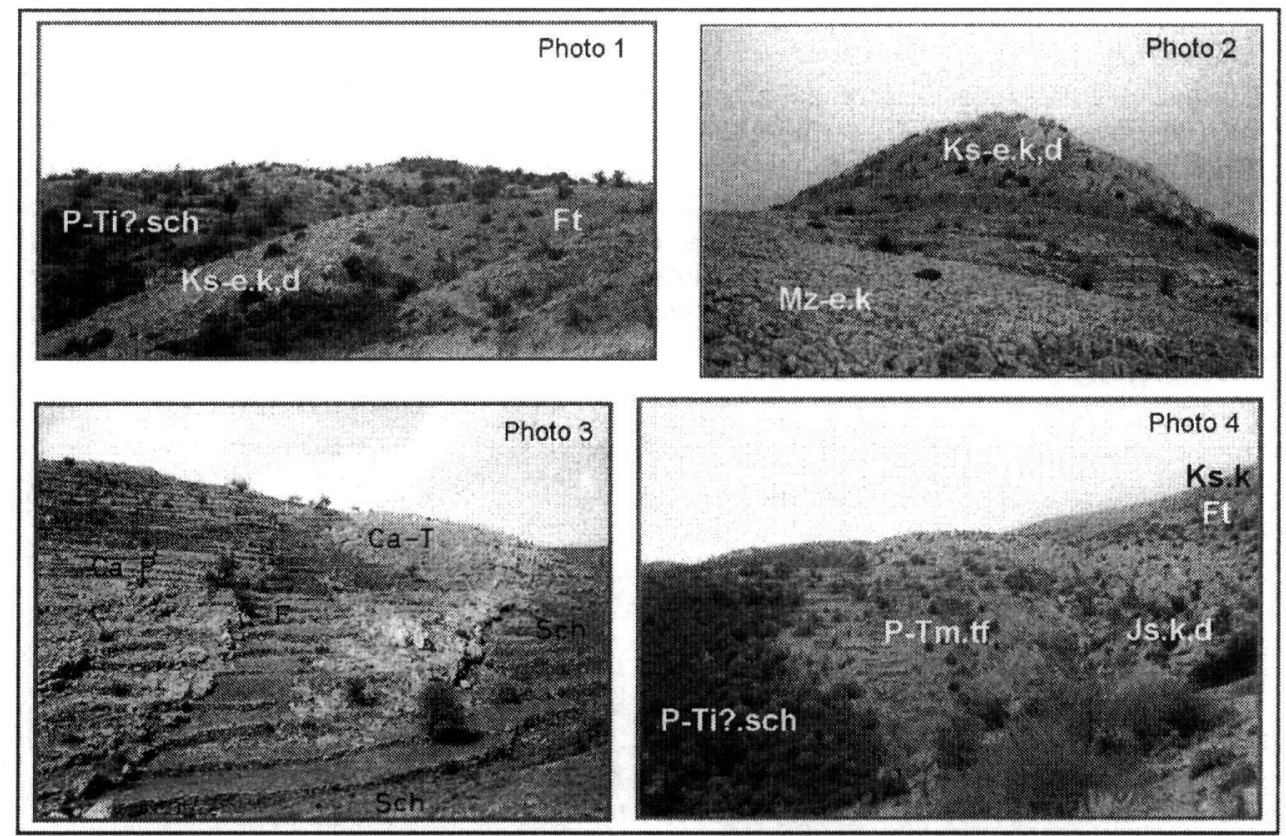

Fig.5: Upper-Cretaceous-Eocene limestones of small thickness overlying through a low-angle normal fault the Phyllites-Quartzites (photo 1). Upper-Cretaceous limestones of the Tripolitza unit overlying multicolored marbles of the Plattenkalk (photo 2). Wedged outcrops of the sediments of the Tripolitza unit sandwiched between the Pindos nappe and the Phyllites-Quartzites (photo 3 and 4). The locations of the photos are shown in figures 2 kal 3.

Moreover, in the west of the study area the metamorphic core of Vlachokerasia is found, the upper plate of which seems intensely faulted by at least two generations of normal faults, some of which appear today horizontal or having low angles (Skourtsos et al. 2001). According to Skourtsos et al. (2001) the fault contacts between the underlying metamorphic and the overlying nonmetamorphic units represent high-angle normal faults that acted within the brittle part of the crust, which during the extensional process rotated so that they came to be parallel with the low-angle tectonometamorphic discontinuity. In the process described above the Tyros Beds and the Phyllites-Quartzites act as a thick detachment horizon in which the upper plate faults anastomose and refract thus forming a great scale "boudinage" structure.

The presentation of the deformation phases above shows that the tectonic evolution that took place in Peloponnesus presents similarities to that of Crete. Kilias et al. (1994) and Fassulas et al. (1994) describe an initial compression phase that led to the nappe formation stacking to the south (Fassulas et al. 1994). This phase was followed by an extensional event accompanied by the formation of detachments and the thinning of the nappes of the non-metamorphic units (Kilias et al. 1994, Fassulas et al. 1994, Jolivet et al. 1994, 1996, Thomson et al. 1998, 1999).

Kilias et al. (1994), Fassulas et al. (1994) proposed that this extensional stage took place in coaxial conditions striking N-S. On the contrary, Jolivet et al. $(1994,1996)$ and Thomson et al. $(1998$, 1999) support a non-co-axial theory and suggest a dominant sense of shear "the top to the N". This extensional phase preceded the neotectonic deformation of the area with the formation of Neogene basins, which started in Serravallian (Le Pichon \& Angelier, 1979, Meulenkamp et al. 1994, Jolivet et al. 1994, Thomson et al. 1998, 1999). The difference existing in the sense of shear of these deformation events on Crete with those found in the study area and in central-eastern Peloponnesus (Skourtsos 2002) is due to the curving of the external part of the Hellenic arc.

The faults that were formed after the detachment phase have caused co-axial extension of the study area striking mainly E-W. This direction is in accordance with the general neotectonic setting of southern Peloponnesus as far as western Crete, that is, an extensional stress field with faults 
striking NW-SE and ENE-WSW to E-W stretching (Lallemant 1984, Hatzfeld et al. 1990, Armijo et al.1991, 1992). This extensional phase affected the already thinned nappe column from the Lower Pliocene and then as continental sediments aged Late Pliocene-Quaternary (Luttig 1964) have been deposited in the post-alpine basins of Megalopolis and Tripolis formed by the high-angle normal faults.

\section{CONCLUSIONS}

The structure of the tectoric window of Doliana is the result of three deformation phases that affected the geotectonic units found in the area, from the Upper Oligocene until today. The first compression phase led to the formation of a heterogeneous nappe-column stacked to the W-SW. Then the non-metamorphic nappes and the Phyllites-Quartzites unit suffered ENE-WSW extension which formed the visible today low-angle normal faults and caused the thinning of the upper nonmetamorphic units, as it is shown by their thickness. A characteristic example of this is the thinning of the nappe of the Tripolitza unit, which from an initial thickness of at least three kilometers (conservative estimations) before the beginning of the extensional process reached a thickness of only a few meters or even zero in the central part of the metamorphic core. So the initially continuous and of great thickness outcrok,s of the upper units ended up in the end of the first extensional phase forming relics of small thickness, which were in essence, contrary to the corresponding compression structures, extensional nappes or klippens. After the Lower Pliocene a second extensional phase affects the already thinned nappe-column with the formation of high-angle normal faults, a phase which also corresponds to the neotectonic deformation and is responsible for the formation of the Tripolis plateau.

\section{REFERENCES}

Armijo R., Lyon-Caen H. \& Papenastassiou D., 1991. A possible normal-fault rupture for the 464 BC Sparta earthquake: Nature, v. 351, p. 137-139.

Armijo R., Lyon-Caen H. and Papanastassiou D., 1992. East-west extension and Holocene normal-fault scarps in the Hellenic arc: Geology, v. 20, p. 491-494.

Bassias I. 1984. Etude geologique du domaine parnonien (feuille d' Astros au 1:50.000) Peloponnese oriental. Unpublished These de 3eme cycle, P. et M. Curie.

Bassias I. 1988. Recristallisation syntectonique et gradient P/T inverse dans les Plattenkalk ioniens Du Parnon (Peloponnese, Grece). C. R. Acad. Sci. Paris 307(Serie II), 627-633.

Bassias I. \& Lekkas S. 1989. La serie transition entre les zones de Tripolitza et du Pinde dans la region d'Eleokhorion-Mont Parthenicn (Peloponnese, Grece). Ann. Soc. Geol. Nord CVII, 297-304.

Bassias I. \& Triboulet C. 1987. Tertiary Pressure-Temperature-Time paths from the Metamorphic External Hellenides, Peloponnesus (Gre€ce). In: Evolution of Metamorphic Belts, Joint Meeting with IGCP PROJECT 235, University College Dublin, Ireland, 17-20.

Blümor T. 1998. Die Phyllit-Quarzit-Serie SE-Lakoniens (Peloponess, Griechenland): Hochdruckmetamorphite in einem orogenen Keil, Frankfurter.

De Wever, P., 1975, Etude geologique de series apparaisant en fenetre sous l'allocthone pindique (serie de Tripolitza, serie epimetamorrinique de Zarouchla), Peloponnese septentrional, Grece: These 3eme cycle thesis, Lille, $318 \mathrm{p}$.

Dercourt J. 1964. Contribution a l'etude geologique d'un secteur du Peloponnese septentrional. Ann. Geol. Pays Hell. 15,418 .

Dercourt, J., De Wever, p. and Fleury, J., 1976, Donnees sur le style tectonique de la nappe de Tripolitza en Peloponnese septentional (Grece): Bull. Soc. geol. France, v. (7), 28, p. 317-326.

Doutsos T., Koukouvelas I., Poulimenos G., Kokkalas S., Xypolias P. \& Skourlis K. 2000. An exhumation model of the south Peloponnesus, Greece. International Journal of Earth Science 89, 350-365.

Fassulas C., Kilias A. \& Mountrakis D. 1994. Post-nappe stacking extension and exhumation of the HP/LT rocks in the island of Crete, Greece Tectonics 13, 127-138.

Hatzfeld D., Pedotti G., Hatzidimitriou P., Panagiotopoulos D., Scordilis E., Drakopoulos J., Makropoulos K., Delibassis N., Latoussakis J., Baskoutas J. \& Frogneux M. 1989. The Hellenic subduction beneath the Peloponnesus: first results of a mizroearthquake study. Earth and Planetary Science Letters 93, 283-291.

Jolivet L., Daniel J., Truffert C. \& Goffe B. 1994. Exhumation of deep crustal metamorphic rocks and crustal extension in arc and back-arc regions. Lithos 33, 3-30. 
Jolivet, L., Goffe, B., Monie, P., Truffert, C., Patriat, M. \& Bonneau, M. 1996. Miocene detachment in Crete and exhumation P-T-t paths of high pressure metamorphic rocks. Tectonics 15, 1129-1153.

Kanavos, V. 1989. Petrogenesis of metamorphic formations in central Peloponnesus. Unpublished Phd thesis, University of Patra (in Greek).

Kilias, A., Fassulas, C. \& Mountrakis, D. 1994. Tertiary extension of continental crust and uplift of Psiloritis metamorphic core complex in the central part of the Hellenic Arc (Crete, Greece). Geol. Rundsch. 83, 417430.

Kowalczyk, G. \& Dittmar, U. 1991. The metamorphic underlying the Plattenkalk carbonates in the Taygetos Mts (Southern Peloponnese). Bull. Soc. Geol. Greece XXV(1), 455-468.

Lallemant, S. 1984. La tranverséle Nord-Maniote. Etude geologique et aeromagnetique d'une structure tranverse a l'arc Egeen externe. Unpublished These, 3eme cycle thesis, Universite Pierre et Marie Curie.

Le Pichon, X. \& Angelier, J. 1979. The Hellenic arc and trench system: a key to the neotectonic evolution of the eastern Mediterranean area. Tectonophysics 60, 1-42.

Lekkas, S. 1978. Donnees nouvelles sur la stratigraphie et la structure de la region au se de Tripolis (Peloponnese central). Ann. Geol. Pays Hell. 29(1), 226-264.

Lekkas, S. \& Zambetakis-Lekkas, A. 1980. Sur l'existence de la serie de Magassa en Peloponnese central (Grece). Ann. Geol. Pays Heli. 30(1), 332-341.

Luttig, G. 1964. Die nichtmarineา "Neogen" - Becken im Mittelmeerraum und ihre Bedeutung fur die Stratigraphie. In: Intern. Union Geci. Proc. 3rd Session Berne, Berne, 148-157.

Meulenkamp, J. E., van der ZWAAN, G. L. \& van Wamel, W. A. 1994. On late Miocene to recent vertical motions in the Cretan segment of the Hellenic Arc. Tectonophysics 234, 53-72.

Richter D., 1974, Die Palaogeographische und geotektonische Bedeutung der Gavrovo-Tripolis-Zone auf dem Peloponnes (Griechenland): N. Jb. Geol. Palaont., v. 145, p. 96-128.

Richter D. 1976. Das Flysch-Stadium der Helleniden-Ein Uberblick. Z. dt. geol. Ges. 127, 467-483.

Skourtsos E. 2002. The geological structure of the eastern boundaries of the tectonic window of Parnon Mt. Unpublished Phd Thesis, Natior,al and Kapodistrian University of Athens, 396p (in Greek with extended English abstract).

Skourtsos E., Alexopoulos, A. \& Lekkas S., 2001. Tectonic structure and evolution of the upper plate of Vlahokerasia metamorphic core complex (Central Peloponnesus). Bull. Geol. Soc. Greece, 34(1), 217-226 (in Greek with English abstract).

Tataris, A \& Maragoudakis N., 1965. About the Upper Triassic and Jurassic stratigraphy of Tripolitza Zone in Kynouria (Peloponnesus). Bull. Geol. Soc. Greece, 6(2), 353-364 (in Greek).

Theye T. \& Seidel E. 1991. Petrology of low-grade high-pressure metapelites from the External Hellenides (Crete, Peloponnese). A case study with attention to sodic minerals. Eur. J. Mineral. 1991(3), 343-366.

Thiebault, F. 1982. Evolution ge Jdynamique des Hellenides externes en Peloponnese meridional (Grece) 6 . Societe Geologique du Nord, 393.

Thomson, S., Stöckhert, B. \& B'ix, M. 1998. Thermochronology of the high-pressure metamorphic rocks of Crete, Greece:Implications for the speed of tectonic processes. Geology 26(3), 259-262.

Thomson, S., Stöckhert, B. \& Brix, M. 1999. Miocene high-pressure metamorphic rocks of Crete, Greece: rapid exhumation by buoyant escape. In: Exhumation Processes: Normal faulting, Ductile flow and Erosion (edited by Ring, U., Brandon, M. T., Lister, G. S. \& Willett, S. D.). Special Puplications 154. Geological Society of London, 87-107.

Trotet, F. 2000. Exhumation of high pressure - low temperature metamorphic rocks along a transect from the Cyclades to the Peloponnese (Greece) - Geodynamic implications. Unpublished Ph.D. thesis, Ecole Normale Superieure. 